\title{
SOUTH CAUCASUS AS A REGION OF STRATEGIC IMPORTANCE
}

\author{
Natalia Bekiarova \\ Prof.Ph.D., National Defense College, Sofia, Bulgaria, nataliab@abv.bg
}

\begin{abstract}
The article 'South Caucasus as a Region of Strategic Importance' provides a detailed analysis of the geopolitical characteristics of South Caucasus as a region with unique position on the world map. It justifies the topicality of the subject and the strong interest in the region populated by diverse ethnicities and religious denominations, exposed to a high concentration of frozen and active conflicts, many border problems, internationally unrecognised and partially recognised states.
\end{abstract}

Revealed are the geographic, ethnic, geo-economic and political characteristics of the region. A focus is placed on the instability in the region and on the existing frozen conflicts on the territory of Azerbaijan and Georgia. Reviewed is the diverging foreign policy orientation of the individual states. The article underscores the geopolitical symbol of South Caucasus as a clashing and conflicting centre of the interests of the big players: Russia, the US, the European Union, Turkey and Iran. Their influence is juxtaposed and the key role of Russia and the USA is highlighted. A special attention is paid to the relationships of the US and NATO with the three South Caucasus republics. The issue of energy security and transportation of energy resources through South Caucasus is seen as central to the conflict of interests of the big geopolitical players. Justified is the understanding that the security environment in South Caucasus is strongly affected by and has lastingly deteriorated as a result of the Ukrainian crisis, the annexation of Crimea and the conflict in Donbas. Another factor behind the complex relationships among the South Caucasus states is their multivector foreign policy orientation and mutually exclusive interests. Georgia appears to be a clear enemy of Russia and makes efforts, by all means, to come closer to the time when it will accomplish its national goals for membership in NATO and the European Union. Armenia in turn is a strategic ally of Russia and a diligent member of the Collective Security Treaty Organisation, dominated by Moscow. Azerbaijan pursues a balanced foreign policy, striving to maintain equally good relations with Russia and with the US and neighbouring Turkey.

In summary it is difficult to find clear positive signs of stability in South Caucasus in the current situation. Russia will continue its efforts to assert its political influence, where this is possible. Against the ongoing situation with the conflicts in the Middle East, in the Black Sea region, in Afghanistan and the complex set-up in the relationships between the US and Iran, the US and NATO policies are expected to intensify further. A conclusion is drawn that the existing status-quo in the relationships of the global geopolitical players would probably develop negatively in the foreseeable future and confrontation will continue for a long period of time.

Keywords: South Caucasus, Black Sea region, geopolitics, conflicts, security environment.

\section{INTRODUCTION}

South Caucasus has a unique position on the world globe. Perhaps for that reason the prominent Russian 
researcher academician Yurii Zhdanov defines it as "the solar plexus of Eurasia” (2019), guided by the understanding that Caucasus plays the same role as that vital centre of the human organism, storing energy and serving as the most important "prop" of the body, radiating power onto all its parts. The definition underscores the critical importance of the region for Russia and for the accomplishment of the Eurasian idea.

Currently the interest in the region is mainly associated with its conflict potential, predetermined by the specific ethno-cultural and political diversity, disputed boundaries among the countries, frozen conflicts and the existing unrecognised and partially recognised states, as well as the lack of constructive solutions to the conflicts. In addition, the importance and the role of the region are due to different conflicting interests and policies of the big geopolitical players, which after the onset of the conflict in Syria have been making continuous efforts to assert their political influence on South Caucasus. The energy component plays a major role in this conflict, particularly the projects for transmission of hydrocarbon energy resources across the Caucasus zone. As a result of the Ukrainian crisis, the annexation of Crimea by Russia and the conflict in Donbas, the security environment in the region has deteriorated continuously and lastingly. Therefore its key position on the political map and the complex combination of problems and security threats have put South Caucasus and the whole Black Sea region at the centre of current international developments.

\section{GEOPOLITICAL ROLE}

Situated between the Black Sea, the Azov Sea and the Caspian Sea, Caucasus has always played a major role in world history. Since earliest historical times it has been viewed as an important geopolitical hub, allowing people to travel deep into the Eurasian continent, control vast land areas and transport networks. This was well known back in the 2nd century B.C. when the Silk Route passed across the northern and southern territories of the Greater Caucasian Range, connecting the North Black Sea coast with China, the Near and Middle East with Europe.

One of the most important geopolitical features of the region emerged after the change in the geopolitical situation following the collapse of the Soviet Union. As a result, the areas to the north of the Greater Caucasian Range remained within the territory of the Russian Federation and the territory of the former Soviet Transcaucasia, the three South Caucasian republics Armenia, Azerbaijan and Georgia became sovereign countries. Thus South Caucasus turned into a separate sub-region not fully formed yet but real from geo-economic and geopolitical point of view, recognised by all the major international players. The total area of South Caucasus together with the area of the separatist regions is little over 186,000 sq. km., with increasing population, which was little over 18 million in early 2019. More than half of the population practices Islam.

In the spirit of classical geopolitics, the historical clash between the Land and the Sea, between thalassocracy and tellurocracy, i.e. between the concept of "water supremacy" against the understanding of "the supremacy by possessing large stretches of land" (2019a) takes place in the zone of South Caucasus. At present that fight is turning into a clash between the territories of the New Atlanticism and the New Eurasianism as historically thalassocracy is associated with the West and the ideology of the Atlanticism, including the U.S., NATO and the European Union countries, while tellurocracy is associated with the East, with the ideology of Eurasianism and Russia.

The unique geopolitical role of South Caucasus is mainly attributable to its location. In the North-South direction, it is situated between the two most actively transforming areas in the world. To the North is the Russian Federation, the biggest country in the world where radical changes have been happening over the last about thirty years or so, relating to the overall redesign of its ideology, socio-economic and state order. To the South is the Greater Middle East whose modernisation is one of the key issues of our modernity. The role of South Caucasus has increased since the onset of the war in Syria, as it borders on Iran and is in close contact with the war zones. In the West-East direction, it is literally a door to the Caspian Sea and Central Asia.

The countries from South Caucasus are generally considered a significant part of the belt of countries belonging to the Western civilisation, to the countries which are loyal to the policy of the West and in particular the United States of America. They play the role of some kind of a "divide", separating the wellbeing and wealth of the North from the poverty and underdevelopment of the South. The Caucasian republics are secular states which have adopted the fundamental principles of democracy, have sufficiently developed their democratic institutions, and respect human rights and freedoms. The years of their being members of the USSR have converted a great part of the population practising Islam to the universal West European values and the people in the region are far from being fanatically religious and from blindly practising Muslim cultural and religious norms.

In the West-East direction, South Caucasus is viewed as a centre of the greater Mediterranean-Black-Sea- 
Caspian region. It includes the countries from South Eastern Europe, South Caucasus and Central Asia. Some of these countries form the south flank of the Greater Europe.

\section{ETHNIC CHARACTERISTICS}

A specific trait of Caucasus and its southern part in particular is the fact that many small and bigger ethnic groups have lived here, on a relatively limited area. The diverse ethnic mosaic reflects the complex historical fate of the region, marked by many invasions of powerful empires and peoples and states that are long gone. The history of Caucasus is the history of the clash of geopolitical interests of the big states since ancient times. The complex accumulation of history and policies has changed its multi-layer ethnic and demographic structure. Many indigenous peoples have disappeared for purely demographic reasons, and other groups have come in their place, which has persistently transformed the ethnic and confession composition of the region. The two main global religions, Christianity and Islam, have been permanently established in Caucasus. For centuries the linguistic set-up, the languages and the written symbols have been changing, further contributing to the typically Caucasian cultural diversity (2019b).

Over 50 ethnic groups of different number live in South Caucasus today, each one with its own original culture, language, faith, ethnic identity, values and interests, distinguishing it from the other peoples. If small nationalities are taken into account, in Azerbaijan alone, at the end of 20th century, the census reports 112 different ethnic groups (2019c), and in the small, partially recognised state of Abkhazia there are 91 groups (Markedonov, 2012). The religion of the people of South Caucasus is mainly Christian for Georgians, Ossetians and Armenians. The Azeri profess mainly Shiit Islam while Abkhazians and Adjarians are Sunni Muslims.

Moreover, the waves of history have left their imprint on the traditional culture, customs and psychological characteristics of indigenous people. The specific temperament and nature of the Caucasian ethnic diversity have been shaped over the centuries.

In the popular and academic literature much attention is paid to the "free Caucasian spirit", "the Caucasian pride", "the Caucasian independent character", the bravery and dignity, "the sun in the blood" of the people living in that region. Thousands of pages have been written on the industriousness, hospitality, toasts and sumptuous Georgian tables. The focus is always on the good sides such as tolerance, restraint and courage, loyalty to the home country and home, to the land of the ancestors, on respect to the elderly people, on the open and friendly relations with neighbours. Caucasians are often referred to as eagles because only the strong and brave eagles inhabit the mountains (2019d).

The study shows that this is an old iconographic image which is to be found mainly in the works of fiction and could have been true for some time in the past, but things have changed now. Time and political circumstances have substantially transformed this bucolic vision. Today Caucasus is stated to be rather a centre of ethnicities - losers who have "holed" in the mountainous areas where it is difficult to live and develop, where "all kinds of human evolution forms" exist. It is viewed as unconceivable how these militant, free spirited "eagles" are readily bowing down to every foreign invader. An answer to the question is sought why, with the huge changes happening in the North and in the South, Caucasians engage in interethnic animosities for fields, pastures, robbing of loads or kidnapping of maidens, things that have nothing to do with nobility and Caucasian bravery. Insistence is placed on the understanding that life in a small area in the inaccessible mountains develops the ability to survive in difficult circumstances rather than getting accustomed to and adhering to no principles, an aptitude to resolve problems through bribes, lies and violence. As the great Russian researcher of Caucasus Vasilii Velichko wrote at the beginning of the 20th century, "The deepest and all-inclusive materialism was the driving force excluding any adherence to principle in the European sense of this word; the harem intrigues and sensitively-oriental psychology in general played an overriding role even in areas illuminated by the light of Christianity" (Velichko, 2007). Further, it is added that in the conditions of Russian autocracy the Caucasian ethnicities have developed a mercenary and pandering psyche so as to preserve themselves. They have developed the perception that in order to survive they invariably needed help from outside (2019e-f). The modern socio-economic and political situation in South Caucasus countries confirms these findings to a certain extent and this is logical against the background of the fierce competition of the big geopolitical players to reinforce their political influence on the countries in the region.

\section{GEO-ECONOMIC AND POLITICAL CHARACTERISTICS}

A modern trait of South Caucasus is the particularly strong economic and political interest in the region. From a geopolitical point of view, its most important role is that of a transit centre through which hydrocarbon pipelines from the Caspian Sea to Europe will pass. Oil and gas reserves of the countries in the region are modest because only Azerbaijan has such resources. The oil reserves are estimated at about $0.6 \%$ of 
proven global reserves, which is about 1 billion tonne or about 7 billion barrels. Natural gas accounts for about $0.8 \%$ of proven global reserves, amounting to about 1.37 trillion cubic metres of blue fuel. At the same time, all surveys show that about $10 \%$ of the global reserves of oil are in the Caspian Sea, part of which belongs to Azerbaijan, and from 4 to $6 \%$ of global reserves of oil are located there $(2019 \mathrm{~g})$. It turns out that the easiest and fastest way for hydrocarbon wealth to reach the international energy markets is through South Caucasus, circumventing the territories of Russia and Iran.

Furthermore, South Caucasus is one of the key regions through which a communication transport hub is to be built, ensuring connectivity via the Europe-Caucasus-Asia transport corridor commonly known as TRACECA. The designed and built communication controls all accesses from North and South and from East and West. It is believed that the one who puts South Caucasus under control, will be able to guarantee itself the leading role in the field of cross-continental transport carriages and communications.

The NATO operation in Afghanistan enhances the importance of the military transit function of South Caucasus, with NATO aircrafts flying over it, and the region is the logistic base of the allied forces. The territories of Georgia, Azerbaijan and Turkmenistan are important part of the so-called "North Distribution Network" for transport of non-military freights to Afghanistan, because the routes via Pakistan are seriously threatened after Osama bin Laden was killed.

Another trait of South Caucasus relates to the fact that in terms of concentration of frozen conflicts, unrecognised and partially recognised states the region ranks first in the world. As a rule, such conflicts and illegitimate states arise in so-called "geopolitical faults". These regions are known as "buffer zones" and are considered strategic breacheads according to different geopolitical concepts. This is one of the reasons why South Caucasus is defined as a zone of permanent conflict.

The partially recognised states are the breakaway regions from Georgia, Abkhazia and South Ossetia. After the war between Georgia and Russia in August 2008 they were recognised by Russia, Venezuela, Nicaragua, and Nauru and from May 2011 by the Pacific Ocean state Vanuatu. Unlike them, the republic of Nagorno-Karabakh is not recognised by any legitimate state.

At present, "the frozen conflicts" on the territory of Georgia do not create serious tension while Russia dominates in the partially recognised Abkhazia and South Ossetia. However, the conflict between Armenia and Azerbaijan for Nagorno-Karabakh is threatening to escalate to the point of war. Along the front line between Azerbaijan and Nagorno-Karabakh, from the signing of the ceasefire in May 1994 to date, there are ongoing shout-outs, killed, injured and captured military men. In the spring of 2016 there was even a fullscale war between the army of Azerbaijan and the self-defence forces of Nagorno-Karabakh. All this, against the background of the quarter-century efforts of the international community in the person of the OSCE Minsk Group for a peaceful regulation and final settlement of the conflict.

The Karabakh conflict in the words of Ariel Cohen, one of the lead experts of The Heritage Foundation, is "one of the most complicated conflicts on the planet" (2019h). The knot of multiple problems weaves historical legacy and modern reality, occupied territories, interests, and ambitions, military successes and defeats, thousands of killed persons, the fates of million refugees and displaced citizens, and a combination of rivalry and different international players.

The prominent US professor from Chicago University Gerard Libaridian compares the Karabakh conflict with a head of onion as it has multiple layers and the more you peel them back, the stronger it smells (2019i). In the opinion of the same expert, the Karabakh conflict differs from the other conflicts in that "any incidental event may provoke its escalation", and in the fact that either party may believe it has prevailed at a certain moment and make use of that. In addition, all surveys show that in both Armenia and Azerbaijan there is a clear lack of willingness of the people for compromises and agreements, which would harm their maximum goals. For the Armenian people this is the establishment of an independent Nagorno-Karabakh state and for Azerbaijan this is the unconditional return of Karabakh and the occupied territories within the country's territories.

It is difficult to establish the number of people killed in the different conflicts due to diverging data. In the Karabakh conflict alone, it is believed that the death toll ranges from 25,000 to 50,000 and the number of displaced refugees by Armenia from Karabakh and the captured regions by Azerbaijan is estimated at over 1 million (Abasov, Hachatryan, 2002).

As a result of the conflicts, South Caucasus is surrounded by many roadblocks. Naturally, due to the conflict in Karabakh, Azerbaijan closed its borders with Armenia. As a sign of solidarity with its "smaller brother", Turkey also has closed its borders with Armenia from 1993 to date. In turn, Erevan blocked access to Nahichevan thus movement to the south through the borders of Armenia is basically possible through Iran. 


\section{FOREIGN POLICY ORIENTATION OF SOUTH CAUCASUS COUNTRIES}

The analysis of the political developments in the three republics in South Caucasus in the last decade shows that they have diverging vector orientation and mutually exclusive interests. Georgia appears to be a clear enemy of Russia (Bekiarova, 2011) and makes efforts, by all means, to come closer to the time when it will accomplish its national goals for membership in NATO, the European Union, and open US military bases on its territory. The main national ideal of Georgia - to restore its territorial integrity - somehow contradicts these goals. Moreover, it is obvious that the country's policy is falling into endless mystification, selfdelusions and counter-productivity in the interpretations of the conflicts in Abkhazia and South Ossetia (2019j). Tbilisi is a partner of Azerbaijan and maintains distant relations with Armenia, as it has serious disagreements about the Armenian population in the Georgian region of Djavahetia. To resolve its problems, the country is undergoing intense militarisation and its military budget has been continuously rising (2019k).

The government of Armenia defines retention of Armenian control over Nagorno-Karabakh by all possible means as the most important national goal. Erevan is the most faithful ally of Russia in South Caucasus, which gets Moscow permanently involved in the region. Armenia relies basically on Russia for its military power. The two countries are part of the Collective Security Treaty Organisation.

Unlike political elites in Tbilisi and Erevan, the regime of I. Aliev in Azerbaijan demonstrates a balanced foreign policy. It shows some respect for the interests of Moscow, Washington, Brussels and Ankara. There is no great enthusiasm for NATO membership or efforts to build energy routes circumventing Russia. The main national priority is to restore the territorial integrity of the country and bring back Karabakh within the country's boundaries. Azerbaijan is being rapidly militarised and in certain periods the country buys weapons at a record level.

A geopolitical symbol of South Caucasus is the fact that it is the place where the interests of the main players clash and compete. All major regional and global powers are competing for influence and dominance in the region. These are mainly Russia, Turkey and Iran as regional powers, and the U.S., NATO and the EU.

Traditionally, South Caucasus is considered the zone of political responsibility and age-old interests of Russia. The country played a huge role in the development of Caucasian peoples back at the end of the 18th century, when it dominated all social spheres. The geographical proximity and, inter alia, the common past, language, culture, family relationships, migration and many other threads link the people from the region with Russia, which undoubtedly prevails over the other countries.

After the collapse of the USSR, for some time Russia was driven out from the political developments in South Caucasus but after the war of August 2008, the annexation of Crimea in 2014, the conflicts in Donetsk and the Middle East, the situation is changing. Russia's return to the so-called post-Soviet space reflects the rationale that the region is dominated by "a growing dependence on external factors which rather cause instability and crises" (Kanchev, 2008).

In the words of the prominent expert Robert Kagan, "what Russia wants today is what great powers have always wanted: to maintain predominant influence in the regions that matter to them, and to exclude the influence of other great powers" (2019l).

For Moscow the region is a zone of immediate vital interests so as to guarantee the security of the Russian Federation. Therefore the country is very sensitive to any attempt by external or regional powers to establish their control here. Russia is concerned over the desire of Georgia and Azerbaijan to join the North Atlantic Alliance. The implementation of this project will make them „a strategic milestone” to expand the influence of the U.S. and the EU in the accesses to neighbouring Iran, the Middle East and Central Asia, defined by Kremlin as a zone of its strategic interests (Stankov, 2019m). Therefore Russia strives to not allow accession to NATO by any of these states and to prevent establishment of US military bases in the region. The other very important issue for Moscow is to prevent the building of routes for transfer of hydrocarbon energy resources outside its control, in circumvention of Russian territories.

Russia employs all possible instruments to assert its influence. This includes military presence in South Ossetia, Abkhazia and Armenia, where it has deployed military bases. Also, the wide range of methods includes supporting political forces and regimes close to Moscow, economic and energy dependencies and other hybrid tools.

The U.S. priorities in South Caucasus are associated mainly with security issues and participation in the management of energy flows from the Caspian Sea zone and transit of energy resources in general from the entire post-Soviet Eurasian space. In addition, the U.S. role in the region is an element of the American strategy for crowding out Russia to the west and to the south. The Washington policy focuses on support of 
democratic development, market reforms and sovereignty of the countries. After the onset of the conflict in Syria and Russia's intervention in it, according to the United States National Security Advisor to the President John Bolton, South Caucasus is a strategically important country for Washington. In this regard, the role of Azerbaijan is most significant, given its common border with Russia and Iran (2019n).

The key instrument of U.S. policy in the region is NATO. Its representatives are establishing close relationships with the political elites in the republics. In addition, they are committed to managing the implementation of the military policies in these countries. Currently, the three South Caucasus states have built relations with the Alliance and are actively participating in the Partnership for Peace programme.

The United States of America is a strategic partner of Georgia and promises support for the country's accession to NATO. Particularly active are the relationships between the two countries in the fields of security and defence. In the summer of 2016 they signed a special agreement on strengthening the defence capacity of Georgia and recently the US support has found expression in the field of its economic development. A big military exercise, Agile Spirit 2019, is to be held under the command of the Georgian armed forces and the U.S. European Command's Army. In the words of the Georgian Prime Minister Giorgi Kvirikashvili, the country's accession to NATO will be "the most prominent value-added to the Euro-Atlantic security" (2019o). At the same time, for many years the pragmatic US policy has not created conditions to accelerate the process of Georgia's membership in NATO. Currently, in the conditions of fierce confrontation between the USA and Russia in the Black Sea region, this issue is back on the agenda again. According to the Secretary General of NATO Jens Stoltenberg, Georgia will join NATO and Russia can do nothing about it, adding that no country has the right to influence NATO's open-door policy, and NATO membership is the choice of the Georgian people (2019p).

From the three South Caucasus republics, Azerbaijan is particularly important, as not only does it rest between Russia and Iran, but it also provides a bridge between Europe and the energy rich Caspian basin. It provides the gateway to the Central Asian states and Afghanistan, removing the need to take a longer and more difficult route through Pakistan. For this reason the Euro-Atlantic integration of Azerbaijan is moving ahead. It should be noted that the diplomacy in Baku is not very enthusiastic and does not state its NATO membership as a main priority.

For identifiable reasons Armenia does not advertise loudly but also develops partnership relations with NATO and is now completing its fifth programme for individual partnership with the Alliance. A new, sixth programme is to be signed in 2020 but it is not possible to talk about NATO accession. Erevan maintains good cooperation with the Alliance, which is important for the country's participation in peacemaking missions in Kosovo and Afghanistan. At the same time, however, Armenia is part of the Collective Security Treaty Organisation. The country is an important partner of Russia and this precludes the possibility for participation in other military and political unions.

The big West European states and EU common policy on South Caucasus is focused on the Neighbourhood Policy, on the Eastern Partnership initiative and on energy security. The region is also significant for EU Member States as a transit zone for goods from Middle Asia and the Caspian basin. In general, the EU has not a comprehensive strategy for development of its relationships with South Caucasus states. The impression is that there is no enthusiasm for participation in the settlement of conflicts and the EU participates with a mission of military observers in Georgia, sent after the conflict in 2008.

The Republic of Turkey is a very proactive player in the geopolitical race for influence in South Caucasus. Since 1993, it has been striving to set up an organisation of the post-Soviet Turkish-speaking states from Central Asia and South Caucasus. In 2007 the $11^{\text {th }}$ congress of the Turkish-Speaking States and Communities Friendship, Brotherhood and Cooperation Foundation was held in Baku. In his address to the congress, Recep Erdoğan insisted on coordination of foreign policy actions of the invited states and for their active involvement in the processes for the settlement of the conflicts in the region. The organisational foundations of the formation were set while insisting on the election of own parliament with three main committees, using exclusively the Turkish language. It insisted on establishment of a sports organisation and on conducting sports events of the Olympic Games type and for the set-up of a single TV company. Currently, Turkey's economic presence is most visible in Georgia and Azerbaijan. Ankara and Baku have closest ties, based on the language kinship, geographic and historical ties.

Iran is the other key regional player with centuries-long traditions in the policy on the South Caucasus zone. The country is in a way a geopolitical competitor of Turkey, although not Turkey, but Russia crowded out Iran from the region. The geopolitical importance of Iran is notable by reason of its border to the south on the Persian Gulf and to the north on the Caspian Sea. The country is one of the bitter enemies of the US. Tehran is a major ally of Armenia and a vehement opponent of Azerbaijan due to the serious ethnic and 
territorial disputes between the two countries and the support provided by the radical Islamists in Azerbaijan (Armencheva, Bekiarova, Ivanov, 2019q; Armencheva, Smolenov, 2015; Armencheva, 2015a; Bekiarova, Armencheva, 2019r; Bonev, 2018; Bonev, 2017; Kalinov, 2018a; Stankov, 2018b; Stankov, 2014; Terziev, Petkov, Krastev, 2018c-k; Terziev, Bankov, Georgiev, 2019I-m).

\section{CONCLUSION}

The problems and stand-offs in South Caucasus reveal it as a miniature model of the world with all existing possible challenges, risks, and threats. It is difficult to find any positive signs of the end of confrontation. Options for settlement of the conflict have not been found yet. Probably the regulation of the conflict for Nagorno-Karabakh would continue for a lengthy period of time and the conflicts on Georgian territory would not be reversed and separatist territories would not be back to the country's territories.

In the foreseeable future, the existing status-quo in the relationships of the global geopolitical players would develop negatively and the confrontation would last for a long period. Russia is expected to make efforts to consolidate the near foreign areas included in the sphere of the exclusive Russian interests, which is clearly demonstrated by the annexation of Crimea, the conflicts in South East Ukraine and the whole Black Sea region. Such a policy does not lead to peacemaking and stability.

The US role in South Caucasus will depend on the situation in the Black Sea region, Central and South Asia and no increase of the US military and political presence is expected for the time being. Given the current developments in the Middle East, in Afghanistan and the unclear future of US-Iran relationships, a more proactive US policy in South Caucasus could be expected.

In the conditions of enhanced commitment by the big geopolitical players it may be expected that Georgia, Armenia and Azerbaijan will gradually realise their common interests and will seek to find paths to one another. This would be a clear sign of their ability to find a reasonable and peaceful solution to their common problems.

\section{REFERENCE LIST}

https://www.kavkaz-uzel.eu/articles/14833/, (2019).

http://cge.evrazia.org/geopolitics_10.shtml, (2019a),

Arutiunov, S.A. (2019b), Ethnicity in the Caucasus: Ethnic Relations and Quasi-Ethnic Conflicts. http://www.circassianworld.com/ethnicity.html.

http://old.iea.ras.ru/topic/census/mon/yunus_mon2001.htm, (2019c).

Markedonov, S. (2012). Defakto obrazovaniya postsovetskogo prostranstva: dvattsat let gosudarstvenogo stroitelystva. Institut Kavkaza, Erevan, 2012 s.48. (Markedonov, S. Дефракто образования постсоветского пространства: дватцат лет государственого строительства. Институт Кавказа, Ереван, 2012 с.48).

http://nationalmentalities.ru/diversity/nacionalnopsihologicheskie_osobennosti_etnosov_rossii/severnyj_kavkaz/serd yuk_yu_o_mentalitet_narodov_kavkaza/, (2019d).

Velichko.V.L. (2007). Caucasus Russian Affairs and Intertribal Problems. Baku, Vatan, 2007. p.12.

https://hdman.livejournal.com/67016.html, (2019e).

http://www.randevu-zip.narod.ru/caucase/caucase.htm, (2019f).

http://cge.evrazia.org/geopolitics_8.shtml, (2019g).

https://www.heritage.org/europe/commentary/turkeys-foreign-policy-plans-2009, (2019h).

http://www.karabakh.org/news/interviews/gerard-libaridian-it-is-quite-possible-for-azerbaijan-to-initiate-waragainst-armenia-p3/,(2019i).

Abasov, A. Hachatryan, A. (2002). Variantay resheniya karabahskogo konflikta: idei i realynosty. BAKU, 2002 (Abasov, A. Hachatryan, А. Варианты решения карабахского конфликта: идеи и реальность. 
БАКУ, 2002).

Bekiarova, N. (2011). Gruziya i Rusiya mezhdu vrazhdata i politikata na "malkite stapki" po patya na dobrosasedstvoto, Georgia and Russia between animosity and the "small steps" policy along the path towards good neighbourhood, (Tri godini sled kraya na petdnevnata avgustovska voyna). Sp. Voenen Zhurnal, br. 1, 2011 g. s.67-78. (Bekiarova, N. Грузия и Русия между враждата и политиката на "малките стъпки" по пътя на добросъседството, Georgia and Russia between animosity and the "small steps" policy along the path towards good neighbourhood, (Три години след края на петдневната августовска война). Сп. Военен Журнал, бр. 1, 2011 г. с.67-78.).

https://www.panorama.am/ru/news/2011/12/01/akhlevdiani/847542, (2019j).

http://radiovesti.ru/news/category/all/22-04-2019/, (2019k).

Kanchev, R. (2008). Zashto Rusiya ne sledva zapadniya model na demokratsiyata? Why Russia does not follow the Western model of democracy?, UI Sv. Kliment Ohridski, 2008, s.173 (Kanchev, R. Защо Русия не следва западния модел на демокрацията? Why Russia does not follow the Western model of democracy?, УИ Св. Климент Охридски, 2008, с.173).

https://geopolitica.eu/2004/1175, (2019l).

Stankov, V. (2019m). Siriyskiyat konflikt i vazmozhnite stsenarii za postigane na stabilnost i mir. Sp. Voenen zhurnal, br. 1-2, 2019. str. 19-20. ISSN 0861 -7392. (Станков, В. Сирийският коноликт и възможните сценарии за постигане на стабилност и мир. Сп. Военен журнал, бр. 1-2, 2019. стр. 19-20. ISSN 0861 -7392).

https://report.az/en/incident/john-bolton-azerbaijan-is-a-strategically-important-country-for-us/, (2019n).

https://www.24chasa.bg/novini/article/6874844, (2019o).

https://news.bg/world/stoltenberg-gruziya-shte-se-prisaedini-kam-nato-rusiya-nishto-ne-mozhe-danapravi.html, (2019p).

Armencheva, I., N., Bekiarova, I., Ivanov. (2019q). Cyber globalization as an in/stability factor. Proceedings of INTCESS 2019-6th international conference on education and social sciences, 4-6 february 2019Dubai, U.A.E. ISBN: 978-605-82433-5-4.

Armencheva, I., Smolenov, S. (2015). From Real Cyber Conflict through Wishful Cyber Security to (un) Likely Cyber Peace, Revista Academiei Fortelor Terestre NR. 3 (79) /2015, p. 260, 2015.

Armencheva, llina. (2015a). Aspects of Policies and Strategies for Cyber security in EU. Journal of Defense Resources Management, 6, 2015, 2, pp. 37-44.

Bekiarova, N. Armencheva, I. (2019r). Is the Peaceful Regulation of the Nagorno-Karabakh Conflict Mission Possible? Proceedings of INTCESS 2019-6th International Conference on Education and Social Sciences, 4-6 February 2019- Dubai, U.A.E. ISBN: 978-605-82433-5-4.

Bonev, R. (2018). Epistemologicheskiyat anarhizam na Pol Fayerabend i geopoliticheskoto modelirane na strategicheskata sreda za sigurnost prez hhi vek. opit za istoriografski pregled. // Voenna akademiya "Georgi Stoykov Rakovski" - 105 godini znanie v interes na sigurnostta i otbranata. Sbornik dokladi ot Mezhdunarodna nauchna konferentsiya 6 - 7 april 2017 g., Sofiya, Voenna akademiya „Georgi Stoykov Rakovski“, 2018, ISBN 978-619-7478-00-6, s. 79-85 (Бонев, Р. Епистемологическият анархизъм на Пол Файерабенд и геополитическото моделиране на стратегическата среда за сигурност през ххі век. опит за историографоски преглед. // Военна академия „Георги Стойков Раковски" - 105 години знание в интерес на сигурността и отбраната. Сборник доклади от Международна научна конференция 6 - 7 април 2017 г., София,, Военна академия „Георги Стойков Раковски“, 2018, ISBN 978-619-7478-00-6, с. 79-85).

Bonev, R. (2017). Koordinatay vneshnepoliticheskoy strategii gosudarstva $v$ teorii mezhdunarodnayh otnosheniy. Savremenni predizvikatelstva pred sigurnostta. Sbornik dokladi ot godishna nauchna konferentsiya na fakultet "Natsionalna sigurnost i otbrana" na VA“G.S.Rakovski" 19-20.05.2016, Vtora chast. S., 2017, ISBN978-954-9348-89-7, s. 91-99 (Бонев, Р.Координаты внешнеполитической стратегии государства в теории международных отношений. Съвременни предизвикателства пред сигурността. Сборник доклади от годишна научна конференция на фракултет „Национална сигурност и отбрана“ на ВА“Г.С.Раковски“ 19-20.05.2016, Втора част. С., 2017, ISBN978-9549348-89-7, c. 91-99).

Kalinov,T. (2018a). Relationships between command, management, and communications. To continue in 
different directions or to remain in same field? Knowledge - International Journal Scientific Papers, vol. 28.6 (December, 2018). ISSN 2545-4439 (printed version), 1857-923X (e-version).

Stankov, V. (2018b). Kam vaprosa za vliyanieto na siriyskata kriza varhu regionalnata ne/sigurnost /. Godishna voennonauchna konferentsiya s mezhdunarodno uchastie na tema,,Savremenni aspekti na sigurnostta - predizvikatelstva, podhodi, resheniya"20 - 21 yuni 2018. Godishnik na Voenna akademiya „G. S. Rakovski“fakultet „Komandno-shtaben“, 2018. ISSN 1312-2991 (Станков, В. Към въпроса за влиянието на сирийската криза върху регионалната не/сигурност /. Годишна военнонаучна конференция с международно участие на тема, Съвременни аспекти на сигурността - предизвикателства, подходи, решения" 20 - 21 юни 2018. Годишник на Военна академия „Г. С. Раковски“фракултет „Командно-щабен“, 2018. ISSN 1312-2991).

Stankov, V (2014). Partiyata na spravedlivostta i razvitieto i savremennata politika za sigurnost i otbrana na Turtsiya, Spisanie „Voenen zhurnal”, 2014/4, str. 77-86, ISSN 0861 -7392. (Станков, В Партията на справедливостта и развитието и съвременната политика за сигурност и отбрана на Турция, Списание „Военен журнал”, 2014/4, стр. 77-86, ISSN 0861 -7392).

Terziev, V., Petkov, M., Krastev, D. (2018c). Operative mode for police cooperation between the member states of the European Union. // Proceedings of SOCIOINT 2018- 5th International Conference on Education, Social Sciences and Humanities, 2-4 July 2018- Dubai, U.A.E, International Organization Center of Academic Research, www.ocerints.org, pp.473-476, ISBN: 978-605-82433-3-0.

Terziev, V., Petkov, M., Krastev, D. (2018d). European arrest warrant: appearance and preferences for fulfillment. // Proceedings of SOCIOINT 2018-5th International Conference on Education, Social Sciences and Humanities, 2-4 July 2018- Dubai, U.A.E, International Organization Center of Academic Research, www.ocerints.org, pp. 477-481, ISBN: 978-605-82433-3-0.

Terziev, V., Petkov, M., Krastev, D. (2018e). Eurojust casework on mafia-type criminal organisations. // Proceedings of SOCIOINT 2018- 5th International Conference on Education, Social Sciences and Humanities, 2-4 July 2018- Dubai, U.A.E, International Organization Center of Academic Research, www.ocerints.org, pp.487-491, ISBN: 978-605-82433-3-0.

Terziev, V., Petkov, M., Krastev, D. (2018f). Concept of joint investigation teams. // Proceedings of SOCIOINT 2018- 5th International Conference on Education, Social Sciences and Humanities, 2-4 July 2018- Dubai, U.A.E, International Organization Center of Academic Research, www.ocerints.org, pp.492-496, ISBN: 978-605-82433-3-0.

Terziev, V., Petkov, M., Krastev, D. (2018f). European arrest warrant and human rights of the accused. // Proceedings of SOCIOINT 2018- 5th International Conference on Education, Social Sciences and Humanities, 2-4 July 2018- Dubai, U.A.E, International Organization Center of Academic Research, www.ocerints.org, pp.501-504, ISBN: 978-605-82433-3-0.

Terziev, V., Petkov, M., Krastev, D. (2018g). Pumps for the action on the European Union in the scope of the European agenda on security. // Proceedings of SOCIOINT 2018- 5th International Conference on Education, Social Sciences and Humanities, 2-4 July 2018- Dubai, U.A.E, International Organization Center of Academic Research, www.ocerints.org, pp.497- 500, ISBN: 978-605-82433-3-0.

Terziev, V., Petkov, M., Krastev, D. (2018h). The process of forming a criminal policy of the European Union. // Proceedings of SOCIOINT 2018- 5th International Conference on Education, Social Sciences and Humanities, 2-4 July 2018- Dubai, U.A.E, International Organization Center of Academic Research, www.ocerints.org, pp.505-510, ISBN: 978-605-82433-3-0.

Terziev, V., Petkov, M., Krastev, D. (2018i). Organization on the European Union in the sphere of penal preparation. // Proceedings of SOCIOINT 2018- 5th International Conference on Education, Social Sciences and Humanities, 2-4 July 2018- Dubai, U.A.E, International Organization Center of Academic Research, www.ocerints.org, pp.482-486, ISBN: 978-605-82433-3-0.

Terziev, V., Petkov, M., Krastev, D. (2018j). Sources of European Union law. // Proceedings of SOCIOINT 2018- 5th International Conference on Education, Social Sciences and Humanities, 2-4 July 2018Dubai, U.A.E, International Organization Center of Academic Research, www.ocerints.org, pp.511516, ISBN: 978-605-82433-3-0.

Terziev, V., Petkov, M., Krastev, D. (2018k). The „Source of law“ category. // Proceedings of SOCIOINT 2018- 5th International Conference on Education, Social Sciences and Humanities, 2-4 July 2018Dubai, U.A.E, International Organization Center of Academic Research, www.ocerints.org, pp.517521, ISBN: 978-605-82433-3-0. 
Terziev, V., Bankov, S., Georgiev, M. (2018I). The Change in the approach of the court of justice of the European Union in the context of market freedoms and internal situations. // Journal of Innovations and Sustainability, Plovdiv, Bulgaria, 4, 2018, 3, pp. 85-112, ISSN 2367-8127 (CD-ROM), ISSN 23678151 (on-line).

Terziev, V., Bankov, S., Georgiev, M. (2018m). The Stability and growth pact: pursuing sound public finances and coordinating fiscal policies in the EU member states. // Journal of Innovations and Sustainability, Plovdiv, Bulgaria, 4, 2018, 3, pp. 53-68, ISSN 2367-8127 (CD-ROM), ISSN 2367-8151 (on-line). 